CORRESPONDENCE

\title{
Medical foot pump compressors have been available for many years as an option for human powered nebulisation
}

npj Primary Care Respiratory Medicine (2014) 24, 14070; doi:10.1038/npjpcrm.2014.70; published online 18 September 2014

\section{Dear Sirs,}

I was intrigued by the recent article by Hallberg et al. ${ }^{1}$ on a human-powered nebuliser as such equipment has been used throughout the world for many years. In 1981 Shann $^{2}$ described giving asthma treatment by a foot pump-driven nebuliser in Papua New Guinea. As an English general practitioner registrar in 1981 I decided that an all-polypropylene version made in the United Kingdom would be very helpful for asthma emergencies in British primary care. ${ }^{3}$ Later a medical version was produced using silicone seals (thus greaseless), stainless steel spring and replaceable filters because foot pump compressors had been described for use in 1950 but oil and particulates released from the mechanism were a cause for concern. ${ }^{4}$ This medical foot pump compressor (www.asthmarelief. co.uk) passed a WHO schedule as it was being considered for use in a nebulised measles vaccination campaign trial that was being proposed by Albert Sabin the oral polio pioneer. It passed hospital evaluation in $1985^{5}$ and by then was in widespread use by general medical practitioners and patients. Its United Kingdom decline was heralded by changes in asthma care, which included the use of inhaled steroids, long-acting inhaled sympathomimetics and especially spacer devices. Nevertheless it remains in production and a patient explained that she carried it on aeroplane flights for use in emergencies. The foot pump compressor success must be reflected in the fact that the Chinese have recently manufactured a new design version of the original robust medical foot pump, but whether it is safe and effective for use is not known.

\section{COMPETING INTERESTS}

The author declares no conflict of interest.

Nigel Masters ${ }^{1}$

${ }^{1}$ Highfield Surgery, Highfield Way, Hazlemere, High Wycombe, UK Correspondence: N Masters (nigel.masters@nhs.net)

\section{REFERENCES}

1 Hallberg CJ, Lysaught MT, Najarro RA, Cea Gil F, Villatro C, Diaz de Uriarte AC et al. Treatment of asthma exacerbations with the human-powered nebuliser: a randomised parallel-group clinical trial. NPJ Prim Care Respir Med 2014; 24: Article number 14016; doi:10.1038/npjpcrm.2014.16.

2 Shann F. Nebulised sympathomimetics in childhood asthma. Lancet 1981; 1: 329.

3 Masters N. An inexpensive nebuliser for asthmatic patients. Practitioner 1983; 227: 1733-1738.

4 Gibbs G. Foot-pump nebulizer. JAMA 1966; 19: 823.

5 Dunn A, Darvell F, Wilson R. An evaluation of the foot pump as a driving source for nebulizer solutions. Br J Dis Chest 1985; 79: 172-176.

This work is licensed under a Creative Commons AttributionNonCommercial-ShareAlike 4.0 International License. The images or other third party material in this article are included in the article's Creative Commons license, unless indicated otherwise in the credit line; if the material is not included under the Creative Commons license, users will need to obtain permission from the license holder to reproduce the material. To view a copy of this license, visit http:// creativecommons.org/licenses/by-nc-sa/4.0/ 